\title{
THE ELECTROPHORETIC ANALYSES OF THE SERUM PROTEINS IN DISEASES OF THE LIVER
}

\author{
By SEYMOUR J. GRAY AND E. S. GUZMAN BARRON \\ (From the Chemical Division of the Department of Medicine, University of Chicago, Chicago)
}

(Received for publication September 4, 1942)

The intimate association of the liver with the maintenance of normal serum proteins is well established. An increase in serum globulin, with inversion of the albumin-globulin ratio, is a common finding in cirrhosis of the liver, but normal serum proteins are observed frequently in the acute parenchymatous diseases of the liver like catarrhal jaundice and arsenical hepatitis (1). The serum protein fractions in cancer of the liver are quite variable.

Determination of the serum proteins by the usual precipitation methods has led to the conception that the proteins may be considered normal when the serum albumin or globulin content falls within the empirically determined normal range. By electrophoretic analysis, however, the protein constituents within the serum globulin may be markedly abnormal, although their sum total by chemical analysis falls within the normal range.

Electrophoretic studies by Luetscher (2) and Longsworth (3) indicate that an increase in beta and gamma globulin, associated with a decrease in albumin, occurs in cirrhosis of the liver. Only a few cases of liver cirrhosis were studied, and most of these investigations were made in the advanced stages of the disease, in which the serum proteins already appeared abnormal by the usual chemical methods. Little is known, however, about the electrophoretic distribution of these proteins in different types of liver disease and in various stages of hepatic insufficiency, particularly in the early stages of liver disease where the serum proteins are presumably normal by chemical analysis.

The present investigation includes the electrophoretic analysis of the serum proteins of patients with acute parenchymatous liver disease, cirrhosis of the liver, and cancer of the liver. Patients with extrahepatic jaundice caused by gall stones were also studied, and the results obtained by electrophoretic and chemical analysis in the various types of liver disease and in extrahepatic jaundice were compared. Patients with varying degrees of liver insufficiency were studied in each group.

\section{METHOD}

The blood samples were obtained from the patients before breakfast. The serum was diluted with 3 parts of veronal buffer made by mixture of the required amounts of $0.025 \mathrm{M}$ veronal, $0.025 \mathrm{M} \mathrm{HCl}$, and $0.025 \mathrm{M} \mathrm{NaCl}$ to a $\mathrm{pH}$ value of 7.8 at $25^{\circ} \mathrm{C}$., and dialyzed against several liters of this buffer for 3 to 4 days, at $3^{\circ} \mathrm{C}$., the buffer being changed daily. The protein solution was then centrifuged at $3^{\circ} \mathrm{C}$. before being introduced into the electrophoresis cell. The electrophoretic experiments were carried out in the Tiselius apparatus (4) at $3^{\circ} \mathrm{C}$., the electrophoretic patterns being recorded by the method described by Longsworth (5).

The concentrations of the components of serum protein were estimated from the electrophoretic diagrams obtained from the descending boundaries.

\section{RESULTS}

\section{Normal serum}

The 4 protein fractions of human serum demonstrable by this method, as first noted by Tiselius (4) and Stenhagen (7), are albumin and

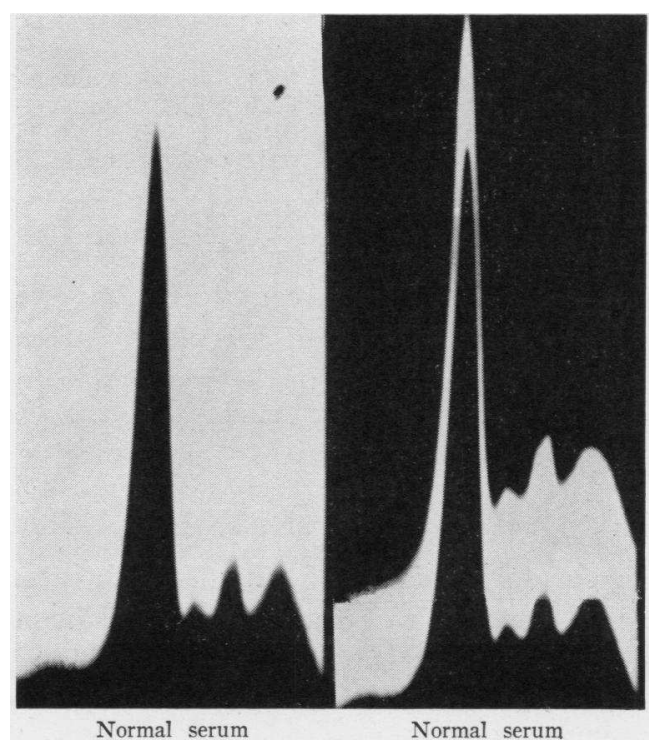

Fig, 1. Normal Serum 
alpha, beta, and gamma globulin, in the order of their electrophoretic mobility. There is excellent agreement among various workers concerning the proportions of these fractions in normal serum. In the 5 normal patients studied here (Figure 1), the serum albumin constituted 62.5 to 65.5 per cent of the total protein, alpha globulin, 6.2 to 7.9 per cent, beta globulin, 12.6 to 15.2 per cent, and gamma globulin, 13.1 to 15.7 per cent (Table I). The average normal values, found in this

TABLE I

Percentage composition of serum proteins in normal serum

\begin{tabular}{c|c|c|c|c|c|c}
\hline \hline Patient & Total protein & A/G ratio & Albumin & $\alpha$ & $\beta$ & $\gamma$ \\
\cline { 2 - 7 } 1 & 7.13 & $4.98 / 2.15$ & 65.4 & 6.2 & 12.6 & 15.7 \\
2 & 7.30 & $4.55 / 2.75$ & 62.5 & 7.9 & 14.6 & 15.0 \\
3 & 7.60 & $4.75 / 2.85$ & 62.8 & 7.5 & 15.1 & 14.6 \\
4 & 7.00 & $4.81 / 2.19$ & 65.5 & 6.4 & 15.0 & 13.1 \\
5 & 7.40 & & 64.0 & 7.1 & 15.2 & 13.7 \\
\hline
\end{tabular}

laboratory, of 64 per cent for serum albumin and 7.0 per cent, 14.5 per cent, and 14.4 per cent for the alpha, beta, and gamma globulins, respectively, closely approximate those reported by Svensson (6), Longsworth (3), Luetscher (2), Gutman (8), and Kekwick (9) (Table II). The high

TABLE II

Ratio of concentration of each globulin/albumin concentration for normal serum

\begin{tabular}{c|c|c|l}
\hline \multicolumn{1}{c|}{$\alpha$ /Albumin } & $\beta /$ Albumin & $\gamma /$ Albumin & \multicolumn{1}{|c}{ Reference } \\
\cline { 1 - 2 } 0.13 & 0.26 & 0.17 & Svensson \\
0.12 & 0.23 & 0.20 & Longsworth \\
0.11 & 0.21 & 0.19 & Luetscher \\
0.12 & 0.21 & 0.26 & Gutman \\
0.08 & 0.19 & 0.43 & Kekwick \\
0.11 & 0.23 & 0.22 & Gray and Barron \\
\hline
\end{tabular}

value for gamma globulin reported by Kekwick is caused by the "delta effect," probably due to diffusion, observed in the ascending boundary. All of our studies were made in the descending boundary to obviate this effect, as suggested by Longsworth and others.

\section{Acute parenchymatous liver disease}

The serum proteins of 5 patients with catarrhal jaundice, and 1 with an acute arsenical hepatitis, were studied electrophoretically (Table III). The catarrhal jaundice patients were between the ages of 5 and 25 and were rather severely jaundiced, with icteric indices between 21 and 40 .
TABLE III

Percentage composition of serum proteins in acute parenchymatous diseases of the liver

\begin{tabular}{|c|c|c|c|c|c|c|}
\hline$\underset{\text { tient }}{\mathrm{Pa}-}$ & $\begin{array}{l}\text { A/G } \\
\text { ratio }\end{array}$ & $\underset{\text { bumin }}{\mathrm{Al}-}$ & $\alpha$ & $\boldsymbol{\beta}$ & $\gamma$ & Diagnosis \\
\hline 14 & $5.62 / 2.23$ & 44.5 & 9.0 & 28.2 & 18.3 & Acute arsenical \\
\hline 29 & $8.75 / 3.71$ & 42.8 & 5.8 & 20.5 & 30.9 & $\begin{array}{c}\text { Catarrhal jaundice } \\
\text { (biopsy) }\end{array}$ \\
\hline $\begin{array}{l}32 \\
33\end{array}$ & $\begin{array}{l}4.33 / 2.45 \\
3.16 / 3.14\end{array}$ & $\begin{array}{l}40.3 \\
48.8\end{array}$ & $\begin{array}{l}7.5 \\
9.1\end{array}$ & $\begin{array}{r}8.0 \\
25.9\end{array}$ & $\begin{array}{l}44.2 \\
16.2\end{array}$ & $\begin{array}{l}\text { Catarrhal jaundice } \\
\text { Catarrhal jaundice }\end{array}$ \\
\hline 42 & $3.79 / 2.75$ & 56.7 & 7.7 & 13.4 & 22.2 & Catarrhal jaundice \\
\hline 68 & $3.91 / 2.25$ & 58.1 & 6.0 & 10.1 & 25.8 & Catarrhal jaundice \\
\hline
\end{tabular}

They presented the typical history and course of an acute infectious hepatitis; biopsy confirmed the diagnosis in 1 patient with catarrhal jaundice (Table III, case 29), and in one with acute arsenical hepatitis (Table III, case 14).

Although the total serum globulin determined chemically by the method of Campbell and Hanna (10) was normal in 3 of the 5 patients with catarrhal jaundice (Table III, cases $32,42,68$ ), electrophoretic analysis revealed an abnormal increase in beta or gamma globulin or both in every instance (Figure 2). The increase of beta globulin to 20.5 and 25.9 per cent noted in 2 patients (Table III, cases 29 and 33) may be considered valid, since the blood cholesterol and the total fats which migrate with beta globulin were normal.

A considerable increase in gamma globulin, with values ranging between 22.2 and 44.2 per cent, was observed in 4 of the 5 cases of catarrhal jaundice. This increase in the gamma globulin to an average of 25.9 per cent and the concomitant decrease in serum albumin are the characteristic protein changes in the acute parenchymatous liver diseases.

That these protein abnormalities may be present in spite of a normal albumin-globulin ratio, determined chemically, is well illustrated in the case of the 5-year-old child with catarrhal jaundice (Table III, case 32). The albumin was decreased to 40.3 per cent and the gamma globulin increased to 3 times its normal value, although the albumin-globulin ratio obtained by the usual fractional precipitation methods remained normal (Figure 3).

Figure 3 also demonstrates the fact that the ascending and descending boundaries are not mir- 


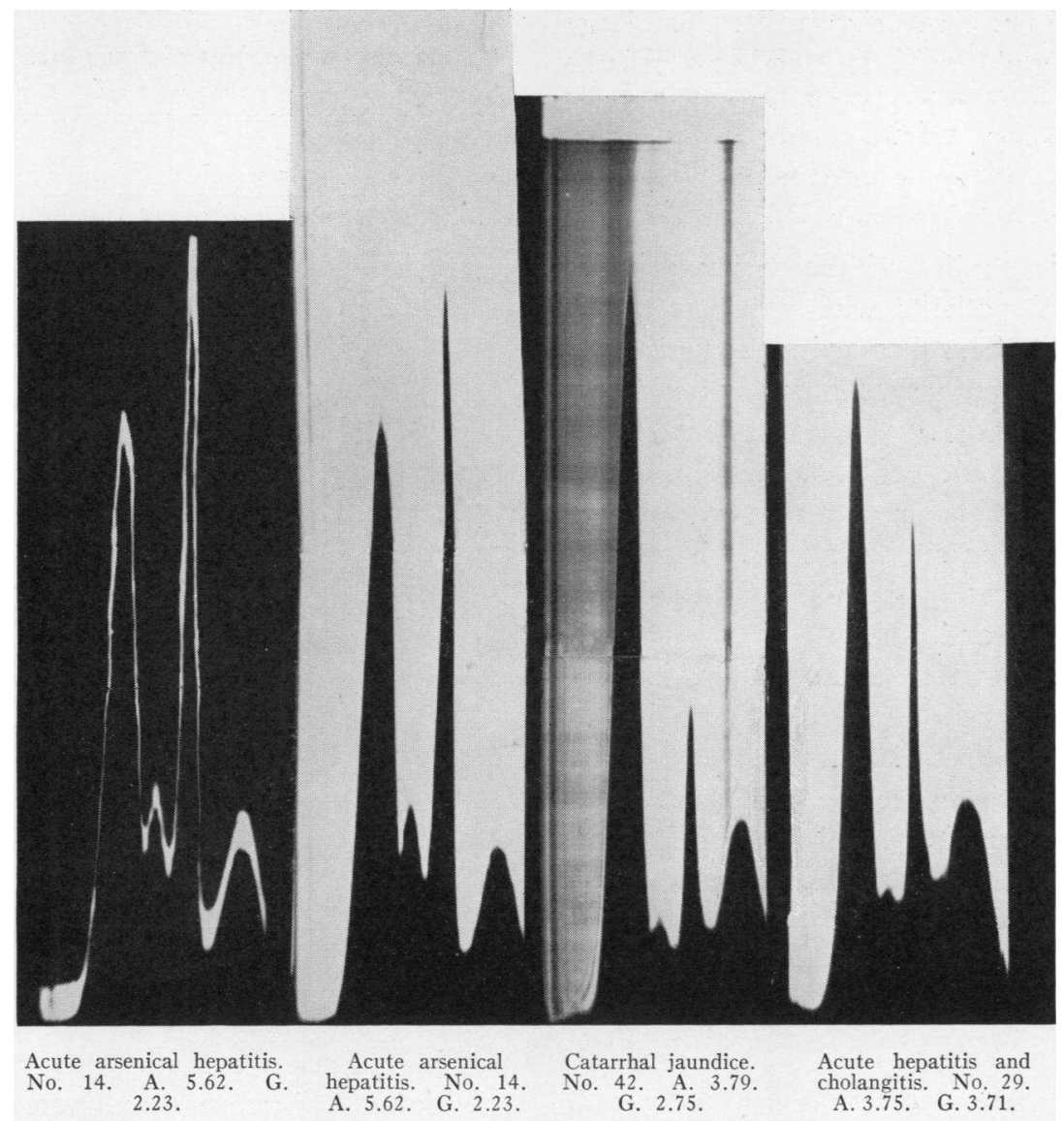

Fig. 2. Acute Parenchymatous Diseases of the Liver

ror images. A fifth protein appears between the beta and gamma globulin in.the anode, and the "delta effect" described by Longsworth may be seen in the very large gamma globulin of the ascending boundary. In the descending boundary,

Catarrhal jaundice. No. 32. A. 4.33 . G. 2.45 .

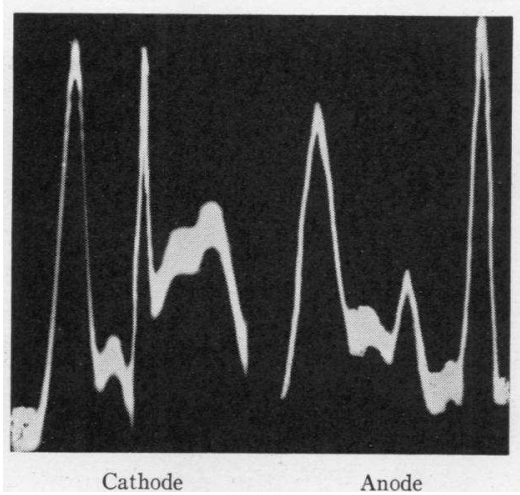

Fig. 3. Catarrhal Jaundice however, the additional protein appears to be a component of the gamma globulin, and the "delta effect" is not observed.

An increase in both beta and gamma globulin was observed in the serum of the patient with acute arsenical hepatitis (Table III, case 14). This 18-year-old patient became severely jaundiced following the third of a series of arsenical injections. The icteric index rose to 150 , and the patient presented the symptoms of complete obstructive jaundice. At operation, no extrahepatic disease was found, and a biopsy of the liver revealed a severe hepatitis with intrahepatic obstruction, characterized by bile casts in the hepatic bile capillaries and edema of the periportal tissue.

Several chemical determinations of the serum proteins revealed a normal albumin-globulin ratio. The serum proteins were abnormal by electrophoretic analysis, however, the albumin being reduced to 44.5 per cent and the gamma globulin 
increased to 18.3 per cent (Figure 2). The large increase in beta globulin to 28.2 per cent may be attributed in part to the high serum cholesterol (714 mgm. per cent).

\section{Cirrhosis of the liver}

Electrophoretic studies of the serum proteins were made in 12 patients with cirrhosis of the liver (Figure 4). The diagnosis was verified in 8 of these cases by autopsy, biopsy, or peritoneoscopy. Atrophic cirrhosis of the liver was found in 6 cases, hypertrophic periportal cirrhosis in 2, polyserositis with cirrhosis of the liver in 1 , and pellagra with atrophic cirrhosis in 1 . These patients were all severely jaundiced with icteric indices between 30 and 120 .

The abnormality of the serum proteins is more pronounced in cirrhosis of the liver than in any other form of liver disease. A decrease in serum albumin or increase in serum globulin, determined chemically, was observed in 9 of 10 cases

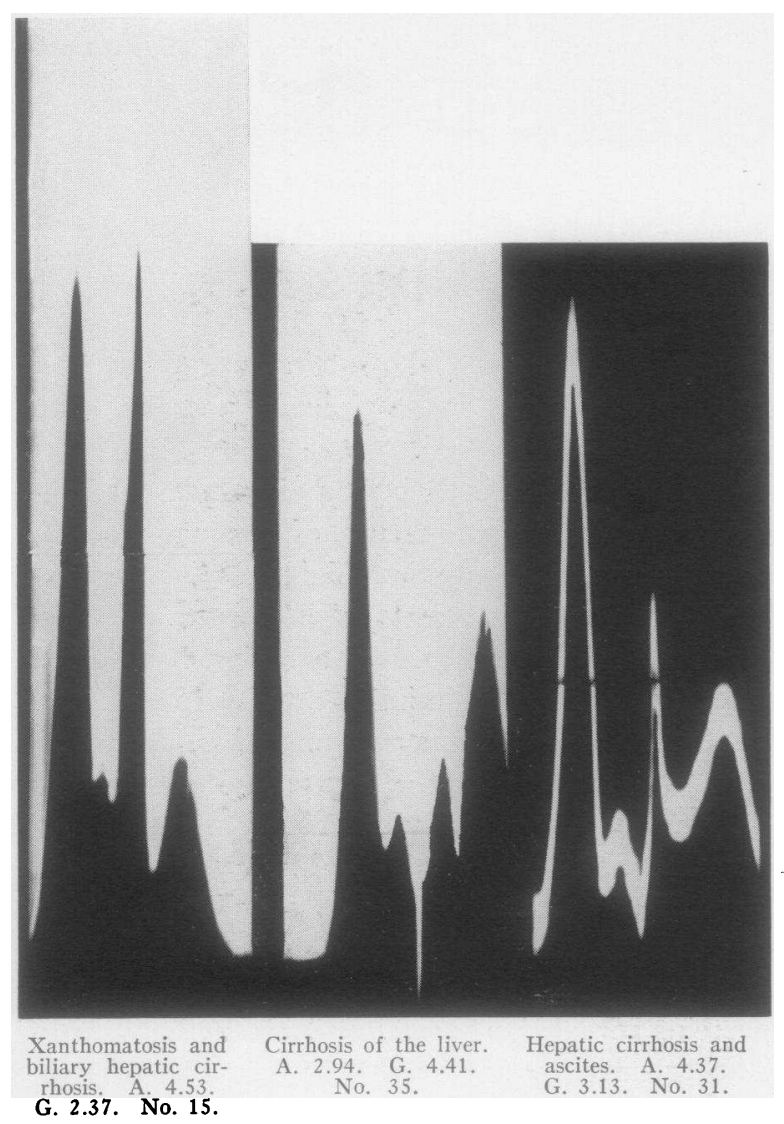

Fig. 4. Cirrhosis of the Liver
TABLE IV

Percentage composition of serum proteins in cirrhosis of the liver

\begin{tabular}{|c|c|c|c|c|c|c|}
\hline $\begin{array}{l}\mathrm{Pa}- \\
\text { tient }\end{array}$ & $\begin{array}{l}\mathrm{A} / \mathrm{G} \\
\text { ratio }\end{array}$ & $\underset{\text { bumin }}{\text { Al- }}$ & $\alpha$ & $\beta$ & $\gamma$ & Diagnosis \\
\hline 7 & $3.60 / 3.04$ & 52.8 & 8.6 & 22.5 & 16.1 & Atrophic cirrhosis \\
\hline 15 & $4.77 / 3.22$ & 45.4 & 4.8 & 30.7 & 19.1 & $\begin{array}{l}\text { Xanthomatosis } \\
\text { and biliary cir- } \\
\text { rhosis (biopsy) }\end{array}$ \\
\hline 20 & $5.11 / 2.54$ & 64.5 & 3.5 & 18.4 & 13.6 & Atrophic cirrhosis \\
\hline 22 & $3.06 / 3.45$ & 36.0 & 5.1 & 14.5 & 44.4 & $\begin{array}{l}\text { Atrophic peripor- } \\
\text { tal cirrhosis (au- } \\
\text { topsy) }\end{array}$ \\
\hline 25 & $1.98 / 2.90$ & 38.1 & 10.5 & 20.6 & 30.8 & $\begin{array}{l}\text { Atrophic cirrhosis } \\
\text { (peritoneoscopy) }\end{array}$ \\
\hline 28 & $3.12 / 2.29$ & 58.8 & 9.1 & 13.6 & 18.5 & $\begin{array}{l}\text { Hypertrophic peri- } \\
\text { portal cirrhosis } \\
\text { (autopsy) }\end{array}$ \\
\hline 31 & $4.37 / 3.13$ & 64.3 & 4.6 & 9.8 & 21.3 & $\begin{array}{l}\text { Pellagra and } \\
\text { atrophic cirrhosis }\end{array}$ \\
\hline 35 & $2.94 / 4.41$ & 42.7 & 10.1 & 12.0 & 34.2 & Atrophic cirrhosis \\
\hline 36 & & 39.9 & 11.7 & 9.2 & 39.2 & $\begin{array}{l}\text { Polyserositis and } \\
\text { capsular cirrhosis } \\
\text { (autopsy) }\end{array}$ \\
\hline 47 & $2.63 / 3.92$ & 39.6 & 9.8 & 14.4 & 36.2 & $\begin{array}{l}\text { Atrophic cirrhosis } \\
\text { (autopsy) }\end{array}$ \\
\hline 61 & $3.23 / 6.02$ & 35.1 & 4.5 & 11.4 & 49.0 & $\begin{array}{l}\text { Hemochromatosis } \\
\text { and cirrhosis }\end{array}$ \\
\hline 62 & & 31.6 & 10.0 & 28.5 & 29.9 & $\begin{array}{l}\text { Hypertrophic cir- } \\
\text { rhosis (autopsy) }\end{array}$ \\
\hline
\end{tabular}

(Table IV). Electrophoretic studies demonstrate even more severe alteration of the serum proteins. Serum albumin was decreased to an average of 45.7 per cent and varied from 31.6 to 64.5 per cent. These determinations were only slightly lower in the 6 cases with ascites than in the 6 without ascites, the average for the former group being 44.7 per cent and for the latter, 46.8 per cent. As many albumin determinations of 31.6 to 39.9 per cent were observed in patients without ascites as in those with ascites, although the 2 normal values of 64.3 and 64.5 per cent occurred in patients without ascites.

The most consistent and characteristic globulin alteration is a large increase in the gamma globulin. This was observed in 11 of the 12 cases studied. The gamma globulin was increased to an average of 29.3 per cent, a 100 per cent increase over the normal. Determinations as high as $36.2,39.2,44.4$, and 49.0 per cent were observed in this group.

Although the beta globulin was increased in 5 of the 12 patients studied, high blood cholesterol values were found in 2 of these cases (Table IV, cases 15 and 62 ). In the remaining 3 cases in which the blood cholesterol and fat were normal, 
the beta globulin constituted 18.4 to 22.5 per cent of the total protein. In general, the average beta globulin for the 10 patients with normal blood cholesterol and fat determinations was normal (14.6 per cent), although moderate increases in the beta globulin were noted in several cases (Table IV, cases 7, 20, 25).

Abnormally high values of 9.8 per cent or more for alpha globulin were observed in 5 cases in which the albumin determinations were particularly low (31.6, 38.1, 39.9, 39.6, 42.7 per cent), and where there was an inadequate compensatory increase in beta and gamma globulin. In other instances with equally low serum albumin and normal alpha globulin values, there were unusually large compensatory increases in beta or gamma globulin (Table IV, cases 22, 61).

\section{Cancer of the liver}

The protein fractions were analyzed electrophoretically in 7 cases of metastatic carcinoma of the liver (Figure 5). The primary source of the carcinoma was the pancreas in 5 cases (Table V, cases $37,54,58,60,64$ ), the stomach in 1 (Table $\mathrm{V}$, case 57 ), and the rectum in 1 (Table V, case
TABLE $V$

Percentage composition of serum proteins in metastatic carcinoma of the liver

\begin{tabular}{|c|c|c|c|c|c|c|}
\hline$\underset{\text { tient }}{\mathrm{Pa}-}$ & $\begin{array}{l}\text { A/G } \\
\text { ratio }\end{array}$ & $\underset{\text { bumin }}{\text { Al- }}$ & $\alpha$ & $\boldsymbol{\beta}$ & $\gamma$ & $\begin{array}{l}\text { Primary source of } \\
\text { liver metastases }\end{array}$ \\
\hline 37 & $5.42 / 3.56$ & 52.7 & 8.6 & 24.2 & 14.5 & $\begin{array}{l}\text { Pancreas (biopsy of } \\
\text { liver) }\end{array}$ \\
\hline 45 & $3.59 / 3.99$ & 45.3 & 6.9 & 18.6 & 28.2 & Rectum (autopsy) \\
\hline 54 & $5.62 / 2.76$ & 60.6 & 8.0 & 19.7 & 11.7 & Pancreas \\
\hline 57 & & 40.0 & 8.6 & 29.2 & 22.2 & Stomach (autopsy) \\
\hline 58 & $4.15 / 2.36$ & 39.5 & 4.7 & 18.4 & 37.4 & $\begin{array}{l}\text { Pancreas (biopsy of } \\
\text { liver) }\end{array}$ \\
\hline 60 & & 58.6 & 9.1 & 20.4 & 11.9 & Pancreas \\
\hline 64 & $3.55 / 2.26$ & 44.7 & 8.7 & 30.1 & 16.5 & $\begin{array}{l}\text { Pancreas (biopsy of } \\
\text { liver) }\end{array}$ \\
\hline
\end{tabular}

45). The diagnosis was confirmed by autopsy or biopsy in 5 of the 7 patients. Jaundice was quite pronounced in each instance, the icteric index varying between 40 and 200 .

The serum albumin-globulin ratio, determined by the fractional precipitation method, was normal in 2 of the 5 cases studied. Electrophoretically, however, the albumin was moderately decreased in 6 of the 7 cases, and varied between 39.5 and 60.6 per cent, with an average of 48.8 per cent.

Abnormalities of the serum globulins are less prominent in secondary carcinoma of the liver

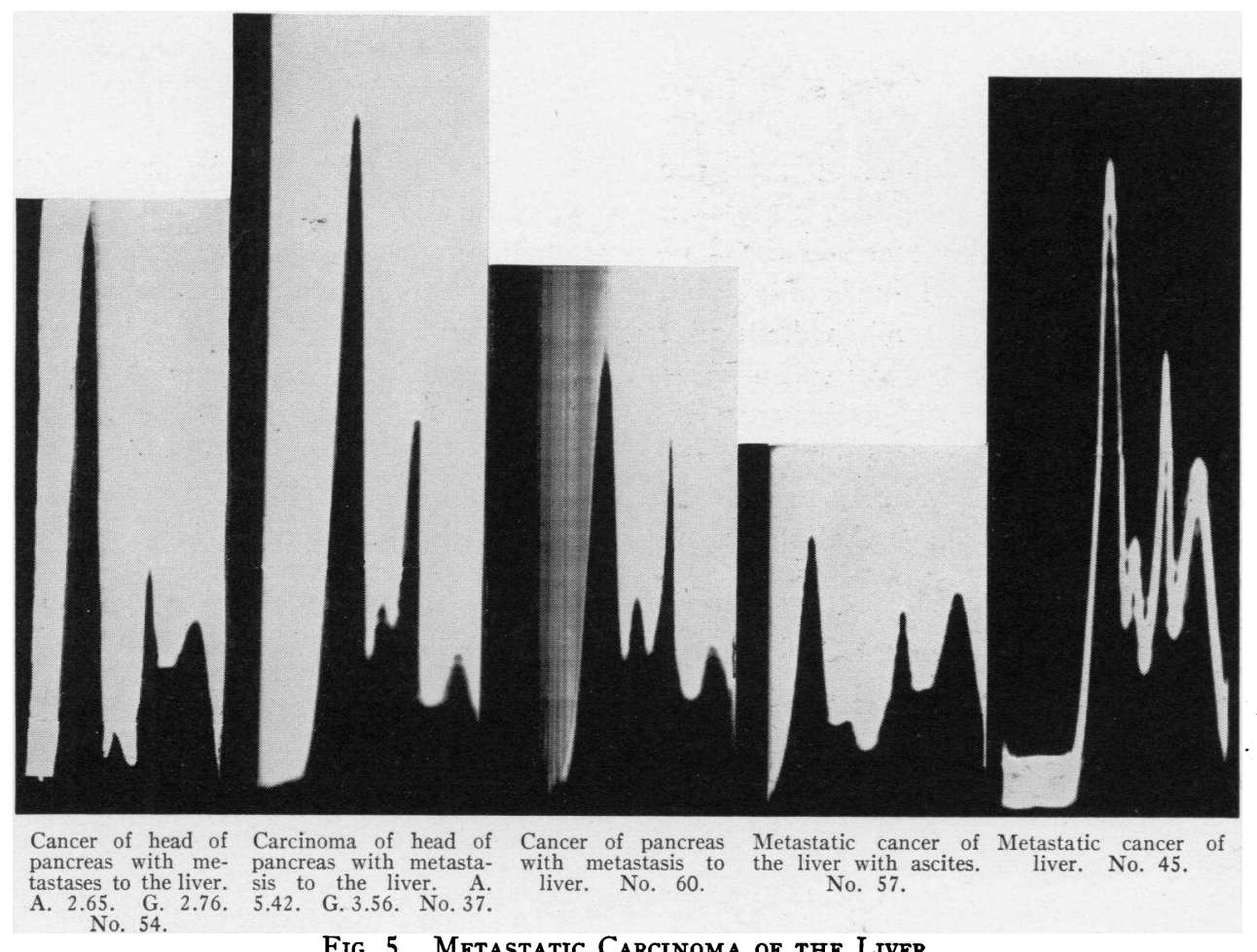

Fig. 5. Metastatic Carcinoma of the Liver 


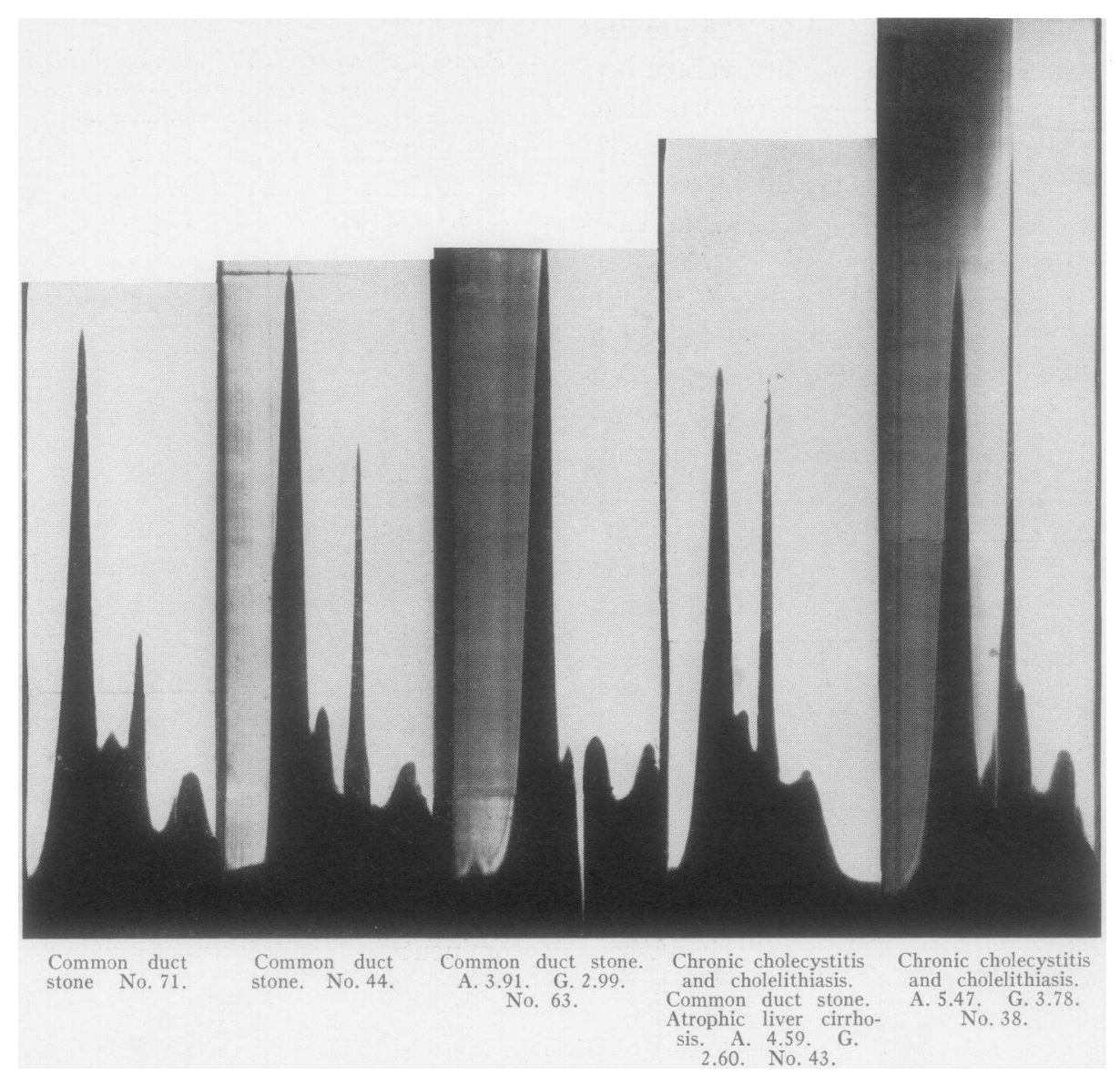

Fig. 6. Extrahepatic Jaundice

than in any other form of intrahepatic disease. The gamma globulin was essentially normal in 4 of the 7 cases, and was increased in the 3 remaining cases. The increase in beta globulin noted in all 7 cases may be explained, in part, at least, by the high blood cholesterol values which were present in the 5 cases with carcinoma of the head of the pancreas. The beta globulin was moderately elevated, however, in 1 case (Table $\mathrm{V}$, case 45) in which the blood cholesterol was normal.

\section{Common duct obstruction}

Jaundice alone does not produce significant alteration of the serum proteins (Figure 6). This fact was demonstrated in 5 patients with a common duct stone, whose livers appeared grossly normal on surgical exploration. The jaundice was quite severe in all cases, as illustrated by icteric indices of $30,32,68,93$, and 125 .
Although the serum albumin was decreased to 50.3 and 53.6 per cent in 2 cases, the gamma globulin was essentially normal in every case. It is interesting to observe that the beta globulin was normal in 2 cases, slightly elevated in 2 cases, and increased to 25.8 per cent in 1 case, although the serum cholesterol determinations were greatly increased in all 5 cases (250 to $416 \mathrm{mgm}$. per cent). (Table VI.)

Case No. 38 deserves special mention. There

TABLE VI

Percentage composition of serum proteins in common duct stone

\begin{tabular}{c|c|c|c|c|c|c}
\hline \hline $\begin{array}{c}\text { Pa- } \\
\text { tient }\end{array}$ & $\begin{array}{c}\text { Total } \\
\text { protein }\end{array}$ & $\begin{array}{c}\text { A/G } \\
\text { ratio }\end{array}$ & $\begin{array}{c}\text { Al- } \\
\text { bumin }\end{array}$ & $\alpha$ & $\beta$ & $\gamma$ \\
\hline 38 & 9.25 & $5.47 / 3.78$ & 50.3 & 8.6 & 25.8 & 15.3 \\
43 & 7.19 & $4.59 / 2.60$ & 66.7 & 8.1 & 18.3 & 6.9 \\
44 & & & 53.6 & 9.1 & 19.6 & 17.6 \\
63 & 6.90 & $3.91 / 2.99$ & 60.7 & 7.6 & 14.8 & 15.9 \\
71 & 6.86 & $4.24 / 2.62$ & 64.6 & 7.6 & 14.6 & 13.2 \\
\hline
\end{tabular}


was in this patient an increase in the total protein concentration of the serum (9.25 per cent). The liver was enlarged; the icterus index was 68.1 ; the cholesterol content was $250 \mathrm{mgm}$. per cent. Whether the large increase in $\beta$ globulin (25.8 per cent) could be attributed to the increased cholesterol, as Longsworth seems to think, was not established. However, the patient when operated for cholelithiasis and cholecystitis (many gall stones were found in the gall bladder) showed in the liver focal areas of necrosis and pyknosis of the nuclei of liver cells. Judging by analogy with the other hepatitis, one is tempted to conclude that the increased beta globulin was a manifestation of the hepatic disorder, confirmed by the microscopic examination.

Albumin-globulin ratios obtained by electrophoretic separation of serum proteins and by fractional precipitation

Electrophoretic analyses of the serum proteins yield lower albumin and higher globulin determinations, and consequently lower albumin-globulin ratios, than are obtained by fractional precipitation (Table VII), although occasionally the results may be identical by both methods.

It should be emphasized that the albuminglobulin ratio or the serum globulin may appear normal as determined by precipitation but definitely abnormal in the distribution of the globulin fractions by electrophoretic analysis. This is most often observed in the acute parenchymatous diseases of the liver, in which the serum proteins are usually normal when determined by precipitation, but markedly abnormal on electrophoretic analysis. It is in these early acute stages of liver disease that these alterations of the globulin fractions are most frequently demonstrated electrophoretically, in spite of normal serum protein determinations on chemical analysis. This was clearly demonstrated in 3 cases of catarrhal jaundice (Table III, cases $32,42,68$ ) and in 1 case of arsenical hepatitis (Table III, case 14), in which the serum globulin or the albumin-globulin ratio was normal by chemical analysis, while the globulin distribution was so abnormal electrophoretically that gamma globulin increases of more than 100 per cent were observed.

Similar but less frequent examples of abnormal
TABLE VII

Albumin-globulin ratios obtained by electrophoretic separation of serum proteins and by fractional precipitation

\begin{tabular}{|c|c|c|}
\hline & \multicolumn{2}{|c|}{$\frac{\text { Albumin }}{\text { Globulin }}$ ratio } \\
\hline & $\begin{array}{l}\text { Electro- } \\
\text { phoresis }\end{array}$ & $\begin{array}{c}\text { Fractional } \\
\text { precipitatior }\end{array}$ \\
\hline $\begin{array}{l}\text { Normal } \\
\text { Normal } \\
\text { Normal } \\
\text { Normal }\end{array}$ & $\begin{array}{l}1.89 \\
1.90 \\
1.67 \\
1.69\end{array}$ & $\begin{array}{l}2.31 \\
2.19 \\
1.65 \\
1.67\end{array}$ \\
\hline $\begin{array}{l}\text { Acute hepatitis and cholangitis } \\
\text { (biopsy) }\end{array}$ & 0.75 & 1.01 \\
\hline $\begin{array}{l}\text { Catarrhal jaundice } \\
\text { Catarrhal jaundice } \\
\text { Catarrhal jaundice } \\
\text { Catarrhal jaundice } \\
\text { Arsenical hepatitis (biopsy) }\end{array}$ & $\begin{array}{l}0.95 \\
0.67 \\
1.30 \\
1.38 \\
0.81\end{array}$ & $\begin{array}{l}1.00 \\
1.76 \\
1.38 \\
1.73 \\
2.52\end{array}$ \\
\hline $\begin{array}{l}\text { Cirrhosis of liver with ascites } \\
\text { (biopsy) }\end{array}$ & 0.65 & 0.67 \\
\hline $\begin{array}{l}\text { Diabetes mellitus and cirrhosis of } \\
\text { liver. }\end{array}$ & 0.54 & 0.54 \\
\hline Atrophic cirrhosis of liver (autopsy) & 0.56 & 0.88 \\
\hline $\begin{array}{l}\text { Xanthomatosis and biliary cirrhosis } \\
\text { (biopsy) }\end{array}$ & 0.83 & 1.48 \\
\hline $\begin{array}{l}\text { Hypertrophic cirrhosis of liver } \\
\text { (autopsy) }\end{array}$ & 1.42 & 1.36 \\
\hline $\begin{array}{l}\text { Carcinoma of pancreas with } \\
\text { metastases to liver (biopsy) }\end{array}$ & 1.12 & 1.52 \\
\hline $\begin{array}{l}\text { Carcinoma of rectum with } \\
\text { metastases to liver (autopsy) }\end{array}$ & 0.86 & 0.90 \\
\hline $\begin{array}{l}\text { Carcinoma of pancreas with } \\
\text { metastases to liver (biopsy) }\end{array}$ & 0.65 & 1.75 \\
\hline $\begin{array}{l}\text { Carcinoma of pancreas with } \\
\text { metastases to liver (biopsy) }\end{array}$ & 0.81 & 1.57 \\
\hline $\begin{array}{l}\text { Common duct stone } \\
\text { Common duct stone }\end{array}$ & $\begin{array}{l}1.98 \\
1.72\end{array}$ & $\begin{array}{l}1.99 \\
2.43\end{array}$ \\
\hline
\end{tabular}

globulin distribution with normal albumin-globulin ratios were seen in cirrhosis of the liver (Table IV, case 20) and in metastatic carcinoma of the liver (Table V, case 58).

The differences in the albumin-globulin ratios obtained electrophoretically and by fractional precipitation are least discernable in cirrhosis of the liver. Here, the serum proteins are so definitely abnormal on chemical analysis that the albuminglobulin ratios determined by both methods approximate each other closely (Table VII). In metastatic carcinoma of the liver, however, the albumin-globulin ratios obtained electrophoretically are more abnormal than is suggested by the chemical determinations, while the $A / G$ ratios in common duct stone are essentially the same by both methods of analysis, and are identical with the control studies. 


\section{DISCUSSION}

These studies indicate that the diseased liver is unable to produce albumin as readily as the normal liver, and the more severe the hepatic insufficiency, the greater is the impairment of albumin production. Consequently, in cirrhosis of the liver with severe diffuse hepatic damage, the protein abnormalties are more pronounced than in any other form of liver disease (Table IV). Albumin values below 40 per cent were observed in 6 cases of cirrhosis of the liver in the late stages of hepatic insufficiency, demonstrating the relationship of severity of disease to impairment of albumin production. The effect of external protein loss will be discussed later. In general, the mean serum albumin was lower in cirrhosis of the liver than in any of the other liver diseases.

Although the degree of liver damage and hepatic insufficiency was considerably less in the patients with acute parenchymatous hepatic involvement, marked impairment of albumin production was observed (Table III). The mean serum albumin determination was 48.5 per cent and values as low as 40.3 and 42.8 per cent were noted, although many of these patients were seen in the early stages of the disease, and none had ascites or albuminuria.

Extensive carcinomatous involvement of the liver caused impaired albumin production, depending upon the degree of liver insufficiency. The lowest albumin value of 39.5 per cent was seen in a patient with extensive carcinomatosis of the liver, without ascites, observed on surgical exploratory examination (Table V, case 58). Values below 50 per cent were observed in 3 other cases, in 1 of which, ascites was present (Table V, case 57). The albumin determinations were not uniformly low in this group, however, as may be noted by such values as $52.7,58.6$, and 60.6 per cent in cases with less extensive liver involvement.

The serum albumin determinations were essentially normal in 3 of the 5 cases of extrahepatic jaundice, although some impairment of albumin production, to 50.3 and 53.6 per cent, was seen in 2 cases. Prolonged jaundice alone may cause early liver damage, and the decreased values may reflect these changes.

It would appear from these observations that the serum protein changes in liver disease result primarily from the inability of the liver to produce normal serum proteins, rather than to external loss of protein to the ascitic fluid. This is in agreement with the observations of several investigators. The albumin-globulin abnormalities may be as severe in the absence of ascites as in cases with massive ascites. This may be confirmed by comparing albumin values of $40.3,42.8$, 44.5 , and 39.5 , observed in patients with liver disease without ascites, to albumin values of 52.8 , 58.8, 42.7, 39.9 and 39.6, noted in patients with ascites. In the 12 patients with cirrhosis of the liver, 6 had ascites and 6 did not. The mean albumin determination was 44.7 per cent in the former group, and 46.8 per cent in the latter, with as many albumin determinations below 40 per cent in one group as in the other. It must be concluded from these studies that although the protein abnormalities may be slightly more pronounced in the patients with ascites than without it, the abnormal protein determinations result primarily from the liver insufficiency itself.

The more severe the impairment of albumin formation in the liver, the greater is the attempt by the body to compensate with an increased output of beta and gamma globulins, especially the latter. Consequently, in cirrhosis of the liver, where the albumin values are lowest, the gamma globulin determinations are highest, consituting 44.4 and 49.0 per cent of the total protein in some cases, and averaging 29.3 per cent more than twice the normal gamma globulin value.

The most consistent and characteristic globulin abnormality in liver disease is the increase in the largest molecular weight fraction, the gamma globulin, and the impaired production of the smallest molecular weight protein, the albumin. These changes are seen most frequently, and to the greatest degree, in cirrhosis of the liver, and next most frequently, in the acute parenchymatous diseases in which the gamma globulin determinations of 44.2 and 30.9 per cent were observed, although the average for this group was 25.9 per cent. The least pronounced gamma globulin abnormalities occurred in cancer of the liver. The gamma globulin values were all normal in extrahepatic jaundice.

The increased beta globulin values are difficult to interpret since the blood lipoids migrate with 
the beta globulin. It should be mentioned, however, that in 5 patients with common duct obstruction and high blood cholesterol determinations between 250 and $416 \mathrm{mgm}$. per cent, the beta globulin was elevated appreciably in only 1 case and to a lesser degree in 2 others. Significant increases in beta globulin (i.e., a beta globulin increase in the presence of normal blood cholesterol) were observed in all the types of liver disease studied, but to a considerably less degree and frequency than the gamma globulin changes. Beta globulin values of $18.4,20.6$, and 22.5 per cent were observed in cirrhosis of the liver, 20.5 and 25.9 per cent in the acute parenchymatous diseases, and 18.6 per cent in metastatic carcinoma of the liver. Disregarding high blood cholesterol determinations, elevated beta globulin values were observed in 5 of the 12 cases of cirrhosis of the liver, 3 of 6 cases of acute parenchymatous liver disease, and in all 7 cases of metastatic carcinoma of the liver. In the latter, the blood cholesterol values were exceedingly high, varying between 340 and 600 mgm. per cent, since the malignancy of the pancreas caused complete long-standing biliary obstruction in 5 of the 7 cases.

It is interesting to observe that in several cases in which the serum albumin was very low (below 40 per cent), and the beta and gamma globulin did not sufficiently compensate for the decrease in albumin, the alpha globulin was increased to 9.8 per cent or more (Table IV, cases 25, 35, 36, 47, $62)$, indicating that in extreme cases where the liver does not adequately compensate by producing an increase in the larger beta and gamma globulin fractions, it may then produce an increase of the smaller alpha globulin as well.

Abnormalities of the serum globulins are less prominent in metastatic carcinoma of the liver than in any other form of intrahepatic disease. This may be explained by the fact that in this disease there are areas of cancer tissue dispersed through and surrounded by normal liver tissue, and since the reserve of the liver is very large, the serum proteins are not appreciably altered until the very late stages of the disease.

Jaundice alone causes little change in the serum proteins, as demonstrated in the 5 patients with common duct stone. Although the icteric indices were quite high in these patients, the serum globulins were essentially normal.

\section{CONCLUSIONS}

1. Electrophoretic analyses of the serum proteins yield lower albumin and higher globulin determinations, and consequently lower albuminglobulin ratios, than are obtained by fractional precipitation.

2. The distribution of the serum globulin fractions may be definitely abnormal electrophoretically in spite of a normal albumin-globulin ratio on chemical analysis.

3. An abnormality of two or more protein fractions was observed in every case of liver disease studied. The degree of abnormality depended on the severity of the disease.

4. The most characteristic alteration of the serum proteins in liver disease is a large increase in the gamma globulin and a decrease in serum albumin. These changes are seen most frequently and to the greatest degree in cirrhosis of the liver and next most frequently in the acute parenchymatous diseases.

5. Significant increases in beta globulin were observed in all types of liver disease, but to a considerably lesser degree and frequency than the gamma globulin changes.

6. Abnormalities of the serum proteins are less prominent in metastatic carcinoma of the liver than in any other form of liver disease.

7. The serum protein changes in liver disease result primarily from the inability of the liver to produce normal serum proteins, rather than from external loss in the ascitic fluid.

8. Jaundice alone does not produce significant serum protein changes.

\section{BIBLIOGRAPHY}

1. Gray, S. J., The colloidal gold reaction of blood serum in diseases of the liver. Arch. Int. Med., 1940, 65, 523.

2. Luetscher, J. A., Jr., Electrophoretic analysis of plasma and urinary proteins. J. Clin. Invest., 1940, 19, 313.

3. Longsworth, L. G., Shedlovsky, T., and MacInnes, D. A., Electrophoretic patterns of normal and pathological human blood serum and plasma. J. Exper. Med., 1939, 70, 399.

4. Tiselius, A., A new apparatus for electrophoretic analysis of colloidal mixtures. Tr. Faraday Soc., 1937, 33, 524.

5. Longsworth, L. G. A modification of the Schlieren Method for use in electrophoretic analysis. J. Am. Chem. Soc., 1939, 61, 529. 
6. Svensson, H., Direkte photographische Aufnahme von Elektrophorese-Diagrammen. Kolloid Ztschr., 1939, 87, 181.

7. Stenhagen, E., Electrophoresis of human blood plasma; electrophoretic properties of fibrinogen. Biochem. J., 1938, 32, 714.

8. Gutman, A. B., Moore, D. H., Gutman, E. B., McClellan, V., and Kabat, E. A., Fractionation of serum proteins in hyperproteinemia with special reference to multiple myeloma. J. Clin. Invest., 1941, 20, 765.

9. Kekwick, R. A., The serum proteins in multiple myelomatosis. Biochem. J., 1940, 34, 1248.

10. Campbell, W. R., and Hanna, M. I., The albumin, globulins, and fibrinogen of serum and plasma. J. Biol. Chem., 1937, 119, 15. 